\title{
Effect of Constructed Wetland Structure on Wastewater Treatment and Its Evaluation by Algal Growth Potential Test
}

\author{
RYUHEI INAMORI ${ }^{1 *}$, PING GUI ${ }^{2}$, YASUTOSHI SHIMIZU ${ }^{1}$, KAIQIN XU², \\ KENJI KIMURA ${ }^{3}$, and YUHEI INAMORI ${ }^{2}$ \\ ${ }^{1}$ Graduate School of Life and Environmental Sciences, Tsukuba University \\ / 1-1-1, Tennodai, Tsukuba, 305-8572, Japan \\ ${ }^{2}$ National Institute for Environmental Studies \\ / 16-2, Onogawa, Tsukuba, 305-8506, Japan \\ ${ }^{3}$ School of Marine Science and Technology, Tokai University \\ / 3-20-1, Shimizuorido, Shizuoka, 424-8610, Japan
}

\begin{abstract}
The enrichment of lakes, inland seas, groundwater and rivers by nutrients such as nitrogen and phosphorus compounds, and their consequences is one of the most severe problems across the world. Transfer of nutrients from different sources into the environment causes eutrophication of surface waters, nitrate accumulation in groundwater, and others. Domestic wastewater is an important nitrogenous and phosphorous source. Among the treatment technologies for it, constructed wetland is emerging as a promising low-cost approach to improve treatment of point and diffuse sources in broad rural areas in developing countries. In this paper, the performance of two typical types of constructed wetlands, FWS (Free Water Surface) and SF (Subsurface Flow) constructed wetlands was investigated on pollutants removal, furthermore, the risk of resulting water bloom for the effluent is also discussed using the parameter of algae growth potential(AGP). The results indicated that the pollutant removal rate measured in the wetland indicated obvious seasonal change. But subsurface constructed wetland indicated more preferable pollutants removal performance and higher stability for wastewater treatment than FWS constructed wetland. The results also indicated that SF constructed wetland could alleviate the effluent's potential of resulting in eutrophication.
\end{abstract}

Key words: Constructed wetlands, Free water surface, Subsurface flow, Domestic wastewater treatment, Nitrogen and Phosphorus, Algal growth potential

\section{INTRODUCTION}

Along with the economic growth, a great deal of wastewater was produced. With the discharge of wastewater into the water body, a lot of nutrients are also brought in. As a result, together with the problem of rivers pollution, water bloom also happened in lakes, inland seas and results in problem for water supply. Though many wastewater technologies have been developed, it is still a difficulty to remove nutrient from wastewater in an economical way. Recently, constructed wetlands have been paid more and more attention for their ability to remove nutrient from numerous, dispersed and relatively small scale waste streams that occur in rural areas around the world, especially for their

\footnotetext{
${ }^{*}$ Corresponding Author: Ryuhei Inamori E-Mail:r_inamori@hotmail.com
} 
relatively low cost, energy and maintenance requirements (Reed and Brown, 1992; Gale and Reddy et al., 1993; Haberl, 1999). As a combination of saturated soil, plants, and microorganisms, constructed wetland could not only remove contaminants by microorganisms (Peter, 1990; Danuta and Andrew, 1992), it could also encourage further nutrient removal through plant uptake (Nicholas, 1983).

With different advantage and disadvantage, two typical types of constructed wetlands according to water level, free water surface (FWS) wetland and subsurface flow (SF) wetlands are usually used now. The present study is aiming to clarify the characteristics of pollutants removals for both kinds of constructed wetlands and is looking forward to giving instruction for constructed wetland design, construction and operation.

Furthermore, the same with other treatment technology, effluent from constructed wetland will be discharged into water environment finally. To evaluate the possibility to result in eutrophication, five traditional parameters were usually evaluated and referred to comprehensively, the transparency, biological indexes such as indicator species and biodiversity index and the amount of algae, primary productivity, concentration of dissolved oxygen and concentration of nitrogen and phosphorous(Sudo, 1983). Evaluation of water quality using all these five parameters is very timeconsuming. Furthermore, since it is evaluated afterwards, abnormal algae growth still can not be predicted, and it is still difficult to take action to prevent algae bloom in advance. Although many researchers gave suggestion on algae bloom and nutrients concentration, they were found to be difficult to explain results when using in practical environment. The nutrients in the practical water are not in a form that can be used by algal, and there may be some substances present in the water that will inhibit algal growth too. To evaluate the potential possibility of resulting abnormal algae growth, a proper method to evaluate potential of algal growth is very necessary. In this study, the parameter of Algal Growth
Potential (AGP) was introduced to determine the maximum amount of algal growth that the nutrients in a water sample can support. This test (APHA 1980; Marvan et al. 1979; Porcella et al. 1970; Miller et al. 1978) provides a better indication of the potential for algal blooms than can be determined by chemical measurement of nutrient concentrations and can give information about the bioavailability of nutrient (D. Couillard et al. 1993; Iwawa Y. et al. 1997). Furthermore, all the evaluation is measured using water from field experiment and is expecting to make clear how water quality will influence AGP evaluation test result and what is the effect of wetland structure.

\section{MATERIALS AND METHODS}

\section{Experimental Systems}

Two pilot-scale FWS and SF constructed wetlands of $50 l \cdot \mathrm{d}^{-1}$ with the HRT of 6 days were constructed in Kokinu Wastewater Treatment Center in Ibaraki prefecture 50 $\mathrm{km}$ Northeast of Tokyo, Japan. The constructed wetlands are a rectangular concrete tank with plastic underlay of $5 \mathrm{~m}$ in length, $0.5 \mathrm{~m}$ in width and $0.9 \mathrm{~m}$ in height. According to the calculation of HRT inside wetlands, sand media was fetched from riverbank and was add to $30 \mathrm{~cm}$ in FWS wetland and $60 \mathrm{~cm}$ in SF wetland. The depth of the water body above the media surface is $10-15 \mathrm{~cm}$ and that for SF wetland is $10-15 \mathrm{~cm}$ lower than media surface. Phragmites australis was planted inside in April. Having different wetland structure, water will flow penetrate the sand and microorganisms in rhizosphere will played the key roles in SF wetland. But in FWS wetland, water will both flow along the surface and penetrate the sand, and all microorganisms attached in rhizosphere, on plant stem and sand surface will work for water purification. Since wastewater was retained inside FWS and SF wetlands to same HRT, the comparison of water quality represent the effect of wetland structure. The raw wastewater of the Wastewater Treatment Center was used in this study. The schematic diagrams of the wetlands are shown in Figure 1. And the influent water quality is shown in Table 1 . 
Table 1 Quality of inflow wastewater used in constructed wetlands

\begin{tabular}{ccccccccc}
\hline \multirow{2}{*}{ Items } & $\begin{array}{c}\mathrm{T} \\
\left({ }^{\circ} \mathrm{C}\right)\end{array}$ & $\begin{array}{c}\mathrm{BOD}_{5} \\
\left(\mathrm{mg} \cdot l^{-1}\right)\end{array}$ & $\begin{array}{c}\mathrm{COD} \\
\left(\mathrm{mg} \cdot l^{-1}\right)\end{array}$ & $\begin{array}{c}\mathrm{TOC} \\
\left(\mathrm{mg} \cdot l^{-1}\right)\end{array}$ & $\begin{array}{c}\mathrm{SS} \\
\left(\mathrm{mg} \cdot l^{-1}\right)\end{array}$ & $\begin{array}{c}\mathrm{T}-\mathrm{N} \\
\left(\mathrm{mg} \cdot l^{-1}\right)\end{array}$ & $\begin{array}{c}\mathrm{NH}_{4}^{+}-\mathrm{N} \\
\left(\mathrm{mg} \cdot l^{-1}\right)\end{array}$ & $\begin{array}{c}\mathrm{T}-\mathrm{P} \\
\left(\mathrm{mg} \cdot l^{-1}\right)\end{array}$ \\
\hline \multirow{2}{*}{ Influent } & $5 \sim$ & $355 \sim$ & $628 \sim$ & $10.28 \sim$ & $37 \sim$ & $23.22 \sim$ & $12.21 \sim$ & $3.37 \sim$ \\
& 28.5 & 477 & 851 & 273.5 & 206.7 & 28.78 & 18.21 & 4.75 \\
\hline
\end{tabular}

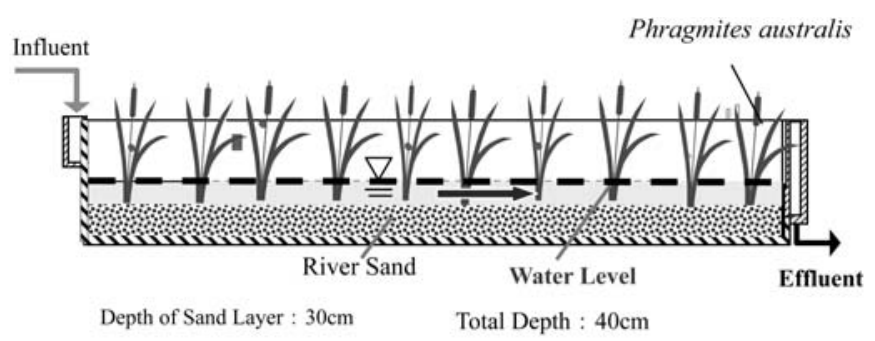

Free Water Surface Flow (FWS) Type

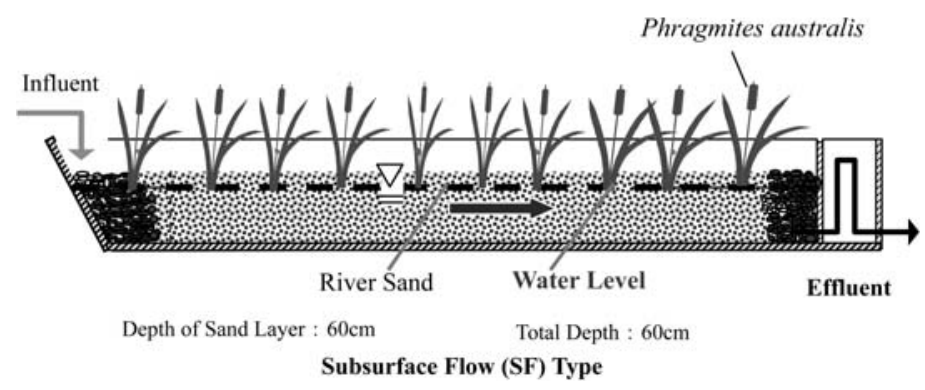

Fig. 1 Schematic diagrams of the two types of constructed wetlands

\section{Analytical Items and Methods \\ Water Sampling and Measurement}

Wetlands influent and effluent water samples were collected from March to December. Along with water sampling, water temperature is also measured. To avoid the influence from diurnal temperature fluctuation, water temperature is measured all at the same time period between $12: 00 \mathrm{pm}$ to 1:00pm all through filed experiment. Water temperature was measured directly in surface water body for FWS wetland and at the effluent tube for SF wetland. Methods for all sample analysis followed guidelines of wastewater quality of Japan (1989). Samples for anions were filtered through a $\mathrm{GF} / \mathrm{C}$ glassfiber filter and were frozen. Aliquots for COD, BOD, and TOC determination were preserved with sulfuric acid $\left(\mathrm{pHB}_{2}\right)$ and stored at $4{ }^{\circ} \mathrm{C}$. The chemical analytical methods from
Standard Methods were adopted for measurements of chemical oxygen demand $\left(\mathrm{COD}_{\mathrm{Mn}}\right)$, biological oxygen demand in five days $\left(\mathrm{BOD}_{5}\right)$ and $\mathrm{SS}$ for the influent and the effluent from the constructed wetlands. TOC is measured using TOC5000A analyzer manufactured by Shimatsu Company of Japan. A Technicon Autoanalyzer TRAACS 800 was used to measure $\mathrm{NH}_{4}{ }^{+}-\mathrm{N}, \mathrm{NO}_{3}{ }^{-}-\mathrm{N}$, $\mathrm{PO}_{4}{ }^{3-}-\mathrm{P}, \mathrm{T}-\mathrm{N}$ and $\mathrm{T}-\mathrm{P}$. For $\mathrm{T}-\mathrm{N}$ and $\mathrm{T}-\mathrm{P}$, samples underwent persulfate digestion and were analyzed for $\mathrm{NO}_{3}{ }^{-}-\mathrm{N}$ by cadmium reduction.

\section{Algal Growth Potential (AGP)}

The AGP test was, basically, carried out according to Miller Et al., 1978 and APHA 1980. According to this method, Selenastrum capricornutu is selected as standard algae. As a kind of unicellular green algae, 
Selenastrum capricornutu is known to be an internationally strandard algal species. Because it can survive in oligotrophic and eutrophic waters, tolerate a wide range of environmental conditions, and keep consistent shape under different environment, it is very suitable to be used as standard algae. Apart from the standard method for integrated algal growth evaluation, the situation of the lake for effluent to discharge was also considered. Here the second largest lake of Japan, Lake Kasumigaura is selected as the objective of evaluation. With the increase in population and industrialization around the lake's drainage basin in recent years, Kasumigaura is also suffering from severe blooms of Microcystis every summer which have seriously damaged carp culture in the lake and caused foul smelling of tap water annually. Furthermore, Microcystis aeruginosa is regarded as a potentially toxic cyanobacterium present in freshwater (lakes, ponds and rivers), and capable of producing a dangerous liver toxin called microcystin. The toxin poses danger to human beings or to animals using the water (Japanese Sewage Works Association, 1992). In this study, Microcystis aeruginosa is selected to test the risk of toxin generation for wetlands effluent. At the same time, considering the potential of resulting in foul tastes and odors for water supply, and considering the unsightly scum which significantly reduce the aesthetic and recreational amenity of the water body, and blockages in pump valves and filters (Japanese Sewage Works Association,1992), Phormidium tenue and Oscillatoria tenuis were also considered.

The test algae were obtained from the National Institute for Environmental Studies. The test alga was grown for 7 days for pre cultivation. Selenastrum capricornutu, Phormidium tenue and Oscillatoria tenuis were cultivated using AAP medium, which is shown in Table 2. Microcystis aeruginosa is cultivated in the 5 times diluted Gorham medium (miller et al., 1978), which is shown in Table 3. When it arrived at the logarithmic phase, algal inoculums were prepared by centrifuging $100 \mathrm{~m} l$ at $3000 \mathrm{rpm}$ for 5 minutes. The supernatant was, carefully, decanted and the residue was resuspended in sterilized
Table 2 AAP Medium

\begin{tabular}{lrl}
\hline \multicolumn{1}{c}{ Medium Components } & \multicolumn{2}{c}{ Amount } \\
\hline $\mathrm{NaNO}_{3}$ & 25.500 & $\mathrm{mg} \cdot l^{-1}$ \\
$\mathrm{~K}_{2} \mathrm{HPO} 4$ & 0.044 & $\mathrm{mg} \cdot l^{-1}$ \\
$\mathrm{MgCl}_{2}$ & 5.700 & $\mathrm{mg} \cdot l^{-1}$ \\
$\mathrm{MgSO}_{4} \cdot 7 \mathrm{H}_{2} \mathrm{O}$ & 14.700 & $\mathrm{mg} \cdot l^{-1}$ \\
$\mathrm{CaCl}_{2} \cdot 2 \mathrm{H}_{2} \mathrm{O}$ & 4.410 & $\mathrm{mg} \cdot l^{-1}$ \\
$\mathrm{NaHCO}_{3}$ & 15.000 & $\mathrm{mg} \cdot l^{-1}$ \\
$\mathrm{H}_{3} \mathrm{BO}_{3}$ & 185.520 & $\mu \mathrm{g} \cdot l^{-1}$ \\
$\mathrm{MnCl}_{3}$ & 264.264 & $\mu \mathrm{g} \cdot l^{-1}$ \\
$\mathrm{ZnCl}_{2}$ & 32.709 & $\mu \mathrm{g} \cdot l^{-1}$ \\
$\mathrm{CoCl}_{2}$ & 0.780 & $\mu \mathrm{g} \cdot l^{-1}$ \\
$\mathrm{CuC}_{2}$ & 0.009 & $\mu \mathrm{g} \cdot l^{-1}$ \\
$\mathrm{EDTA}$ & 7.260 & $\mu \mathrm{g} \cdot l^{-1}$ \\
$\mathrm{Na}_{2} \mathrm{MoO}_{4} \cdot 2 \mathrm{H}_{2} \mathrm{O}$ & 96.000 & $\mu \mathrm{g} \cdot l^{-1}$ \\
$\mathrm{FeCl}_{3}$ & 300.000 & $\mu \mathrm{g} \cdot l^{-1}$ \\
\hline
\end{tabular}

* $\mathrm{pH} 7.5 \pm 0.1$

Table 3 Gorham 5 times diluted Medium

\begin{tabular}{lrl}
\hline \multicolumn{1}{c}{ Medium Components } & \multicolumn{2}{c}{ Amount } \\
\hline $\mathrm{NaNO}_{3}$ & 99.2 & $\mathrm{mg} \cdot l^{-1}$ \\
$\mathrm{~K}_{2} \mathrm{HPO}_{4}$ & 7.8 & $\mathrm{mg} \cdot l^{-1}$ \\
$\mathrm{MgSO}_{4} \cdot 7 \mathrm{H}_{2} \mathrm{O}$ & 15.0 & $\mathrm{mg} \cdot l^{-1}$ \\
$\mathrm{CaCl}_{2} \cdot 2 \mathrm{H}_{2} \mathrm{O}$ & $7.2 \mathrm{mg} \cdot l^{-1}$ \\
$\mathrm{Na}_{2} \mathrm{CO}_{3}$ & $4.0 \mathrm{mg} \cdot l^{-1}$ \\
$\mathrm{Na}_{2} \mathrm{SiO}_{3} \cdot 9 \mathrm{H}_{2} \mathrm{O}$ & 11.6 & $\mathrm{mg} \cdot l^{-1}$ \\
$\mathrm{EDTA}$ & $1.0 \mathrm{~g} \cdot l^{-1}$ \\
$\mathrm{Citric}$ Acid & $1.2 \mathrm{mg} \cdot l^{-1}$ \\
Iron(III) Citrate Trihydrate & 1.2 & $\mathrm{mg} \cdot l^{-1}$ \\
Gaffron Trace Element Solution & 0.8 & $\mathrm{~m} l$ \\
\hline
\end{tabular}

* $\mathrm{pH} 7.5 \sim 8.0$

Table 4 Gorffron Trace Elements Stock Solution

\begin{tabular}{|c|c|c|}
\hline Medium Components & \multicolumn{2}{|c|}{ Amount } \\
\hline $\mathrm{H}_{3} \mathrm{BO}_{3}$ & 3.100 & $\mathrm{mg} \cdot l^{-1}$ \\
\hline $\mathrm{MnSO}_{4} \cdot 4 \mathrm{H}_{2} \mathrm{O}$ & 2.230 & $\mathrm{mg} \cdot l^{-1}$ \\
\hline $\mathrm{ZnSO}_{4} \cdot 7 \mathrm{H}_{2} \mathrm{O}$ & 0.287 & $\mathrm{mg} \cdot l^{-1}$ \\
\hline$(\mathrm{NH} 4)_{6} \mathrm{Mo}_{7} \mathrm{O}_{24} \cdot 4 \mathrm{H}_{2} \mathrm{O}$ & 0.088 & $\mathrm{mg} \cdot l^{-1}$ \\
\hline $\mathrm{CuSO}_{4} \cdot 5 \mathrm{H}_{2} \mathrm{O}$ & 0.125 & $\mathrm{mg} \cdot l^{-1}$ \\
\hline $\mathrm{Co}\left(\mathrm{NO}_{3}\right)_{2} \cdot 6 \mathrm{H}_{2} \mathrm{O}$ & 0.146 & $\mathrm{mg} \cdot l^{-1}$ \\
\hline $\mathrm{Al}_{2}\left(\mathrm{SO}_{4}\right) 3 \mathrm{~K}_{2} \mathrm{SO}_{4} \cdot 24 \mathrm{H}_{2} \mathrm{O}$ & 0.474 & $\mathrm{mg} \cdot l^{-1}$ \\
\hline $\mathrm{NiSO}_{4}\left(\mathrm{NH}_{4}\right)_{2} \mathrm{SO}_{4} \cdot 6 \mathrm{H}_{2} \mathrm{O}$ & 0.198 & $\mathrm{mg} \cdot l^{-1}$ \\
\hline $\mathrm{Cd}\left(\mathrm{NO}_{3}\right)_{2} \cdot 4 \mathrm{H}_{2} \mathrm{O}$ & 0.154 & $\mathrm{mg} \cdot l^{-1}$ \\
\hline $\mathrm{Cr}\left(\mathrm{NO}_{3}\right)_{2} \cdot 7 \mathrm{H}_{2} \mathrm{O}$ & 0.037 & $\mathrm{mg} \cdot l^{-1}$ \\
\hline $\mathrm{V}_{2} \mathrm{O}_{4}\left(\mathrm{SO}_{4}\right)_{2} \cdot 16 \mathrm{H}_{2} \mathrm{O}$ & 0.035 & $\mathrm{mg} \cdot l^{-1}$ \\
\hline $\mathrm{Na}_{2} \mathrm{WO}_{4} \cdot 2 \mathrm{H}_{2} \mathrm{O}$ & 0.033 & $\mathrm{mg} \cdot l^{-1}$ \\
\hline $\mathrm{KBr}$ & 0.119 & $\mathrm{mg} \cdot l^{-1}$ \\
\hline KI & 0.083 & $\mathrm{mg} \cdot l^{-1}$ \\
\hline
\end{tabular}


distilled water. This step was repeated twice. The inoculums were left to stand for 2 hours. Three replicate culture flasks were used for each treatment.

Then $200 \mathrm{~m} l$ of sample was prepared and filtrated by three layers of GF/C filter paper. Before it was used for AGP test, they were filtrated by $0.45 \mu \mathrm{m}$ filter again to remove the bacteria and the algae in the water sample and then moved to the sterilized flask.

Then the flasks were inoculated with the test alga to obtain 1,000 cells $\cdot \mathrm{m}^{-1}$ as final algal density (For Microcystis aeruginosa, 10,000 cells $\cdot \mathrm{m} l^{-1}$ should be obtained.). To avoid dioxide limitation, the sample to flask volume ratio was kept in the range of 1:5. Flasks were incubated at $25{ }^{\circ} \mathrm{C}$ for 14 days under continuous illuminations of cool white fluorescent tubes providing 4,000 lux (For Microcystis aeruginosa, it was incubated at 30 $\left.{ }^{\circ} \mathrm{C}\right)$. To ensure free gas exchange, the culture flasks were plugged with silicon rubber bung and shaken at the speed of $800 \mathrm{rpm}$ during the incubation period.

During the course of incubation, the amount of alga was calculated using microscope. When the test alga attained its maximum standing crop, the incubation was stopped and the gravimetric determination of algal dry weight was carried out by centrifuging a suitable volume of algal culture. The supernatant was carefully decanted and the sediment algal cells were washed with distilled water, centrifuged, transferred to dry pre-weighed crucibles, dried in a hot air oven at $105^{\circ} \mathrm{C}$, cooled down in desiccators for one hour, and then reweighed to obtain the average algal dry weight. And the final result of AGP was expressed in the unit of $\mathrm{mg} \cdot l^{-1}$.

\section{RESULTS AND DISCUSSION}

\section{Performance of Pollutant Removals}

Effluents from both wetlands were found to change along the season and fluctuate with the status of the plant. System operation was divided into three phases. Phase A is the period when plant is not put into the wetland. When Phragmites australis was planted inside, the operation is described as Phase B. After winter came after late October, air temperature fell down, plant withered and it is called Phase C.

As shown in Figure 2, which give the pollutants removal performance from two constructed wetland, both wetland systems showed not low removal efficiency even in Phase A when Phragmites australis was not planted inside. It is estimated to be owing to the adsorption of pollutants by sand inside both constructed wetlands. Then pollutants removal efficiencies began to decrease until Phase B after the raising of Phragmites australis inside. It suggested that it will take at least one month before the sufficient growth of rhizosphere and stable performance of pollutants removals were obtained. During the whole course of operation, although SF also showed to have unstable operation period, this process seemed to be very short. Moreover, no matter for TOC, or for COD and BOD, SF wetland kept to obtain stable removals of higher than $80 \%$ most of the time and it was even higher than $92 \%$ up to October. On the contrary, pollutants removals in FWS wetland were obvious fluctuations in Phase A before plants were put in, and Phase $\mathrm{C}$ after plants were withered. On several sampling days, the removal efficiency of TOC, COD, BOD was only around $30 \%$. And removal efficiency of around $50 \% \sim 60 \%$ also often happened. During stable operation period of FWS wetland, most of the removal efficiency was higher than $80 \%$, but some fluctuation still occurred and then removal efficiency was only $60 \%$. Considering SS removal, the advantage of SF wetland showed to be more obvious. During the whole operation period, SS removal rate was higher than $85 \%$ in SF wetland and most of the time it was higher than $90 \%$. But for FWS wetland, it was very unstable. Sometime, no obvious removal was found. And most of time, it was lower than $50 \%$.

Figure 3 presents the performance of nutrients removals such as $\mathrm{NH}_{4}{ }^{+}-\mathrm{N}, \mathrm{T}-\mathrm{N}$ and $\mathrm{T}-\mathrm{P}$ in both systems. Similar to pollutants removal, no matter for $\mathrm{NH}_{4}{ }^{+}-\mathrm{N}, \mathrm{T}-\mathrm{N}$ or T-P, $\mathrm{SF}$ system showed removal efficiencies of higher than $88 \%$, and except at the beginning of Phase A before plant was put in and at late Phase $\mathrm{C}$ when plant withered completely, its removal efficiency kept stable. For FWS 

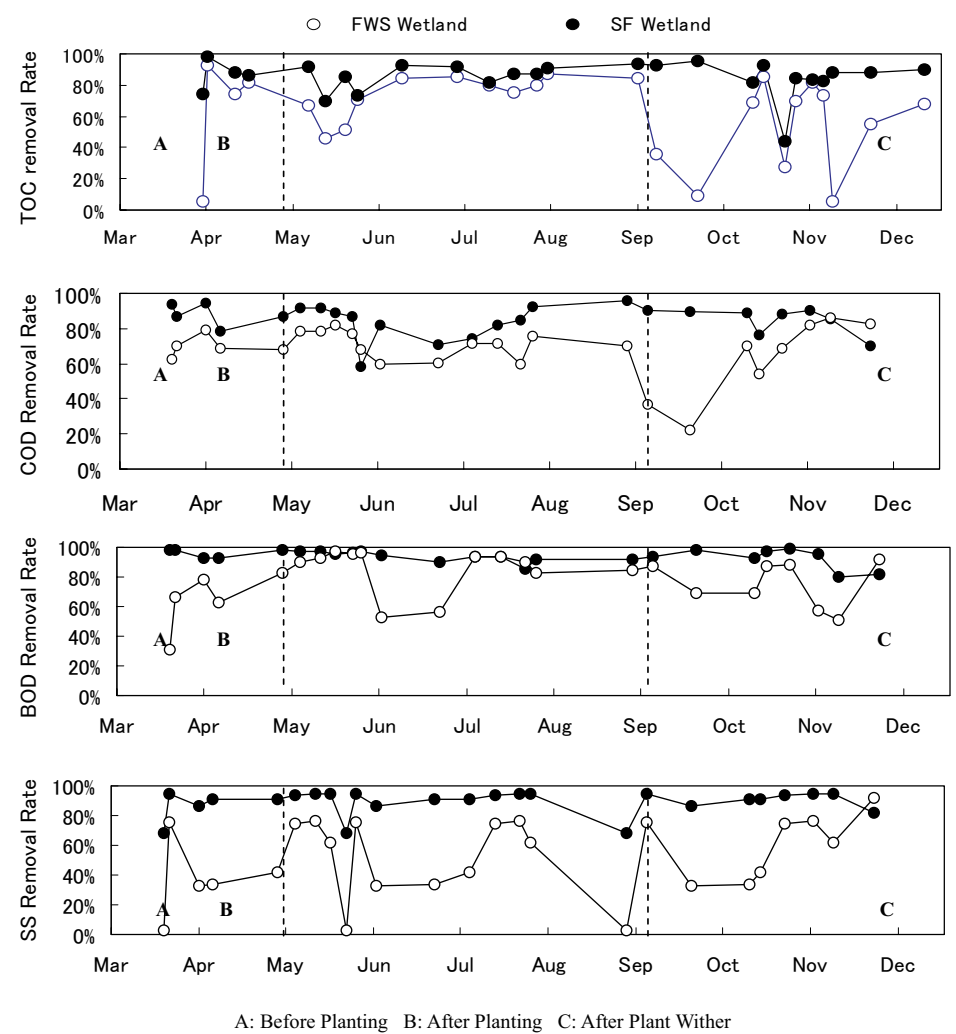

Fig. 2 Temporal changes of TOC, COD, BOD, and SS removals in constructed Wetlands

wetland, same tendency was found. But the fluctuation was obvious, especially when time entered late winter; removals of $\mathrm{NH}_{4}{ }^{+}-\mathrm{N}, \mathrm{T}-$ $\mathrm{N}$ were lowered than $20 \%$. For T-P removal, FWS didn't get stable removal no matter what season it is. It only reached $50 \%$ except several days in hot summer when plant grew fast. Adsorption is supposed to be the main mechanism for phosphorous removal and the contact of influent and sand media is not sufficient here.

Seen from the pollutants removal and nutrients removal, sharp decreases of BOD and $\mathrm{T}-\mathrm{N}$ removal were found in FWS wetland in winter, but performances of SF wetland only worsen a little and it still showed efficient removal efficiency. Water temperature of FWS wetland was found to be 4 ${ }^{\circ} \mathrm{C}$ and it was frozen after late December but that inside SF wetland kept around $10{ }^{\circ} \mathrm{C}$. This was considered to be the main reason for the differences of pollutants removals in these two wetlands.

To assess performances of both wetlands, the fluctuation and average level of pollutant removal for the whole year was counted (Figure 4).

Compared with SF wetland, the average removal efficiency of $\mathrm{COD}, \mathrm{BOD}_{5}, \mathrm{~T}-\mathrm{N}$ and $\mathrm{NH}_{4}{ }^{+}-\mathrm{N}$ for FWS are around $15 \% \sim 25 \%$ lower than that of SF wetland. And the SS removal and T-P removal for FWS is even more than $35 \%$ lower that of SF wetland. At the same time, the $\mathrm{COD}, \mathrm{T}-\mathrm{N}$ and $\mathrm{T}-\mathrm{P}$ removal rates for SF wetland fluctuate around $35 \%$ and the others only fluctuate lower than $20 \%$, but because of low performance of FWS in winter, the pollutant removals of FWS wetland all fluctuate largely from $40 \%$ to $90 \%$, or even from $10 \%$ to $90 \%$. Considering pollutants removal, $\mathrm{SF}$ was shown to be a better choice in this study.

Evaluation of effluent water quality As 

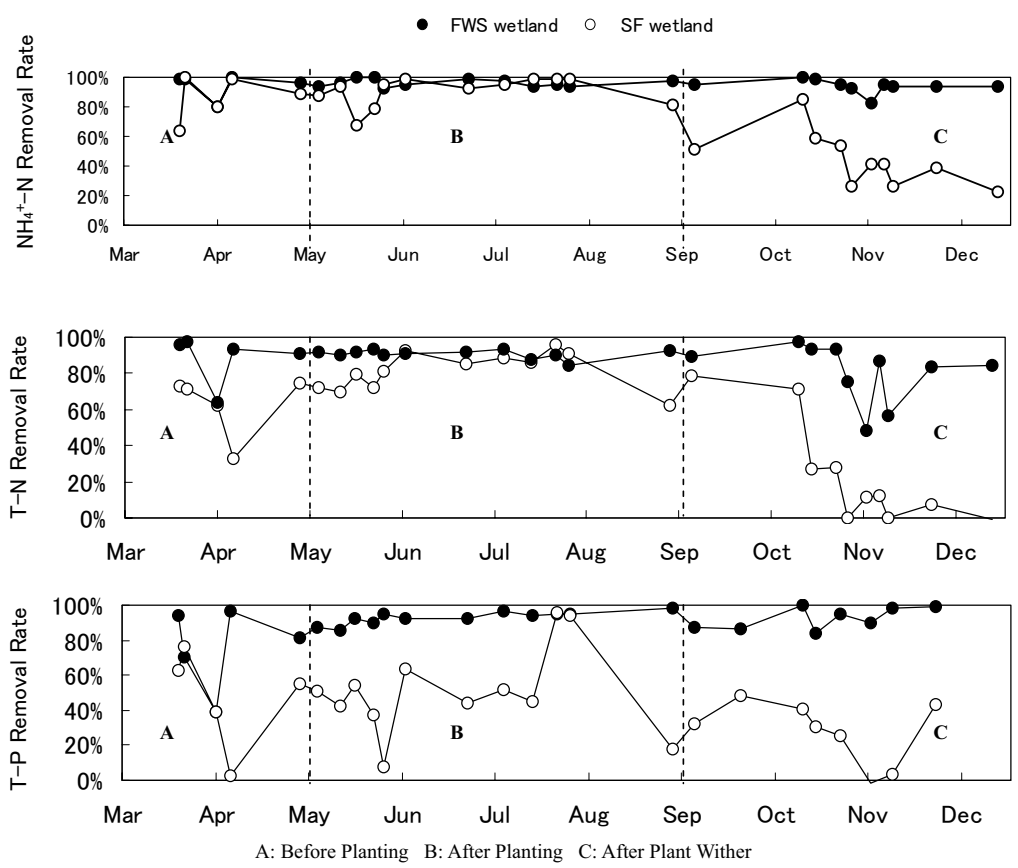

Fig. 3 Temporal changes of $\mathrm{NH}_{4}{ }^{+}-\mathrm{N}, \mathrm{T}-\mathrm{N}$ and T-P removals in constructed Wetlands

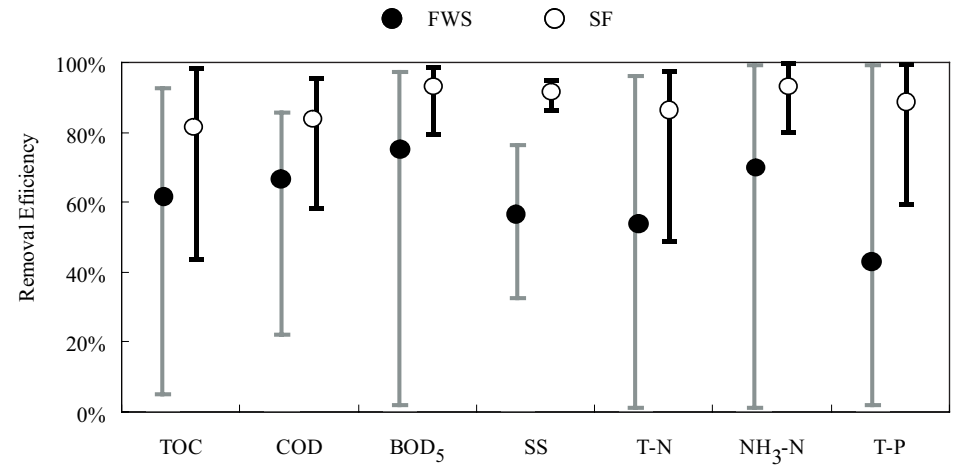

Fig. 4 Average pollutants removals and their fluctuation ranges

mentioned above, to use $\mathrm{A}, \mathrm{B}$ and $\mathrm{C}$ to represent different operation period, the average water quality of influents and effluents from two systems in Phase A, B and $\mathrm{C}$ are shown in Table 5. Seen from this table, for pollutants such as COD, BOD, TOC and SS, since their values fluctuated to some extent at all seasons, the average water quality didn't show so much difference. The same conclusion can still be obtained that water quality of SF effluent is lower than that of FWS effluent and the water quality in Phase B period is the best. Considering the concentration of nutrient in the water, because the water quality of FWS effluent in period C fluctuates obviously, the water quality of FWS effluent in period $\mathrm{C}$ is much higher than the other two periods. On the contrary, because the performance of SF kept being very stable all the time, the nutrient in SF effluent kept to be very low in all three periods. 
As the final fate for treated wastewater, it will be discharged into water environment. According to the regulation on water quality, effluents from constructed wetlands should be investigated the same as effluents from other wastewater treatment plants. The regulation on discharged water quality from wastewater treatment plants prevents water environment pollution. Considering treated wastewater will be discharged into public water body, it prescribed that COD should be lower than $20 \mathrm{mg} \cdot l^{-1}$, BOD $<20 \mathrm{mg} \cdot l^{-1}$, SS $<40 \mathrm{mg} \cdot l^{-1}$. Considering the control of eutraphication, $\mathrm{T}-\mathrm{N}$ should be lower than 20 $\mathrm{mg} \cdot l^{-1}$, and T-P $<1 \mathrm{mg} \cdot l^{-1}$. Seen from Table 5 , effluent from SF wetland can meet all the standards mentioned above at Phase A, B and C. But for FWS wetland, except COD and $\mathrm{T}-\mathrm{N}$ can meet the standard during Phase $\mathrm{B}$, the others can not meet the standard at all.

After Algal Growth Potential (AGP) test, the maximum algal harvest that can be obtained from a water sample after a specific duration in a laboratory environment was determined. Using the algae of Selenastrum capricornutum to indicate the potential of integrated algae growth, using the algae of Microcystis aeruginosa to represent the potential of a kind of live toxin-microcystin generation, which is regarded a big problem for water supply, and using Phormidium tenue and Oscillatoria tenuis to represent the potential of resulting clogging and foul taste for water supply. Since treated wastewater will be discharged into water environment and is diluted to some extent. To make the AGP represent the true potential of treated wastewater for resulting water bloom after the effluent is discharged into the environment, AGP pretest using treated wastewater with different dilution ratio of 5 times, 10 times and 20 times was carried. AGP was closed to each other at dilution ratio of 10 times and 20 times and is higher than dilution ratio of 5 times, so treated water from both constructed wetlands were diluted to 10 times for AGP test using four species of algae in this study. AGP for

Table 5 Average water quality for FWS and SF effluents in different operation periods

\begin{tabular}{|c|c|c|c|c|c|}
\hline \multicolumn{3}{|c|}{ Experimental Period } & \multirow{2}{*}{$\frac{\mathrm{A}}{183.0}$} & \multirow{2}{*}{$\frac{\text { B }}{127.4}$} & \multirow{2}{*}{$\frac{\mathrm{C}}{122.5}$} \\
\hline \multirow{3}{*}{ COD } & \multirow{3}{*}{$\left(\mathrm{mg} \cdot l^{-1}\right)$} & Influent & & & \\
\hline & & FWS Effluent & 50.0 & 37.4 & 41.2 \\
\hline & & SF Effluent & 24.4 & 17.5 & 18.4 \\
\hline \multirow{3}{*}{ BOD } & \multirow{3}{*}{$\left(\mathrm{mg} \cdot l^{-1}\right)$} & Influent & 45.2 & 132.0 & 277.4 \\
\hline & & FWS Effluent & 14.7 & 15.3 & 69.6 \\
\hline & & SF Effluent & 2.2 & 7.1 & 6.7 \\
\hline \multirow{3}{*}{ TOC } & \multirow{3}{*}{$\left(\mathrm{mg} \cdot l^{-1}\right)$} & Influent & 132.40 & 70.55 & 67.85 \\
\hline & & FWS Effluent & 15.62 & 12.99 & 35.00 \\
\hline & & SF Effluent & 16.66 & 13.79 & 12.44 \\
\hline \multirow{3}{*}{ SS } & \multirow{3}{*}{$\left(\mathrm{mg} \cdot l^{-1}\right)$} & Influent & 114.6 & 85.7 & 91.1 \\
\hline & & WS Effluent & 57.5 & 35.9 & 39.9 \\
\hline & & F Effluent & 16.3 & 7.8 & 9.4 \\
\hline \multirow{3}{*}{\multicolumn{2}{|c|}{$\mathrm{NH}_{3}-\mathrm{N}\left(\mathrm{mg} \cdot l^{-1}\right)$}} & Influent & 9.88 & 23.6 & 29.14 \\
\hline & & FWS Effluent & 3.55 & 4.09 & 26.31 \\
\hline & & SF Effluent & 3.63 & 1.53 & 2.50 \\
\hline \multirow{3}{*}{$\mathrm{T}-\mathrm{N}$} & \multirow{3}{*}{$\left(\mathrm{mg} \cdot l^{-1}\right)$} & Influent & 56.48 & 40.23 & 51.95 \\
\hline & & FWS Effluent & 22.74 & 7.82 & 35.88 \\
\hline & & SF Effluent & 7.64 & 3.74 & 7.87 \\
\hline \multirow{3}{*}{$\mathrm{T}-\mathrm{P}$} & \multirow{3}{*}{$\left(\mathrm{mg} \cdot l^{-1}\right)$} & Influent & 8.24 & 5.51 & 6.18 \\
\hline & & FWS Effluent & 3.00 & 2.75 & 4.53 \\
\hline & & SF Effluent & 2.41 & 0.42 & 0.49 \\
\hline
\end{tabular}


effluent from both constructed wetlands considering these four types of algae were determined and the results are shown in Figure 5.

The results showed that AGP of four species of algae for SF wetland effluent is lower than that for FWS wetland, especially for Phormidium tenue and Selenastrum capricornutum. The value for FWS wetland is 15 times and 14 times higher than that for SF wetland effluent respectively. AGP for Oscillatoria tenuis is the lowest among these four species of algae and the AGP for FWS wetland effluent is still three times to that of SF wetland. Considering the AGP for Microcystis aeruginosa, the AGP for FWS wetland effluent and SF wetland effluent is closed to each other. The value for FWS wetland is only 1.4 times higher than that of SF wetland Effluent.

As a comprehensive parameter to evaluate water quality, AGP will be influenced by many factors. Figure 6 shows the relationship with nutrients such as $\mathrm{T}-\mathrm{N}, \mathrm{T}-\mathrm{P}, \mathrm{NH}_{4}{ }^{+}-\mathrm{N}$ and $\mathrm{NO}_{3}-\mathrm{N}$ concentrations.

As shown in Figure 6, the influence of nutrients on effluent AGP of Phormidium tenue, Selenastrum capricornutum and
Microcystis aeruginosa is remarkable, but the variation of AGP based on Oscillatoria tenuis is not so obvious. The variation tendency for Phormidium tenue and Selenastrum capricornutum is very similar to each other. There existed a peak concentration for $\mathrm{T}-\mathrm{N}$, $\mathrm{T}-\mathrm{P}$. Under this concentration, the AGP for Phormidium tenue and Selenastrum capricornutum reached the maximum. Considering these two species of algae, the peak concentrations for $\mathrm{T}-\mathrm{N}$ and $\mathrm{T}-\mathrm{P}$ were 22.5 and $3.3 \mathrm{mg} \cdot l^{-1}$, respectively. Differently, AGP based on Microcystis aeruginosa was positively proportional to $\mathrm{T}-\mathrm{N}$ and $\mathrm{T}-\mathrm{P}$ concentrations.

To investigate the correlation between status of nutrients and AGP, Pearson's correlation is calculated for four species of algae. As shown in Table 6, nutrients are calculated respectively according to organic status, inorganic status and the total value. AGP of Microcystis aeruginosa is found to have statistically significant correlation with nitrogen source, especially orgnic nitrogen source $(\mathrm{P}<0.01)$. It was also reported in other researchers results that the growth and yield of Microcystis aeruginosa were consistently greatest when using organic nitrogen source

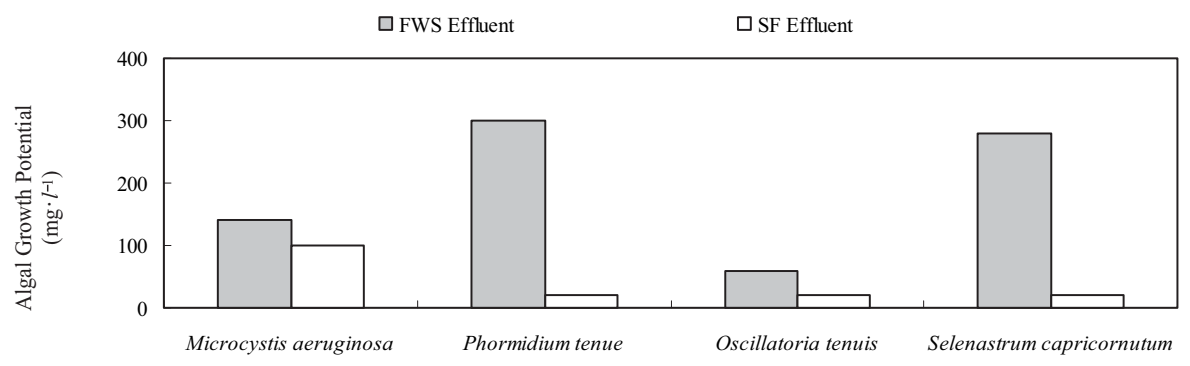

Fig. 5 Algal growth potential of influents and effluents from both types of constructed wetlands
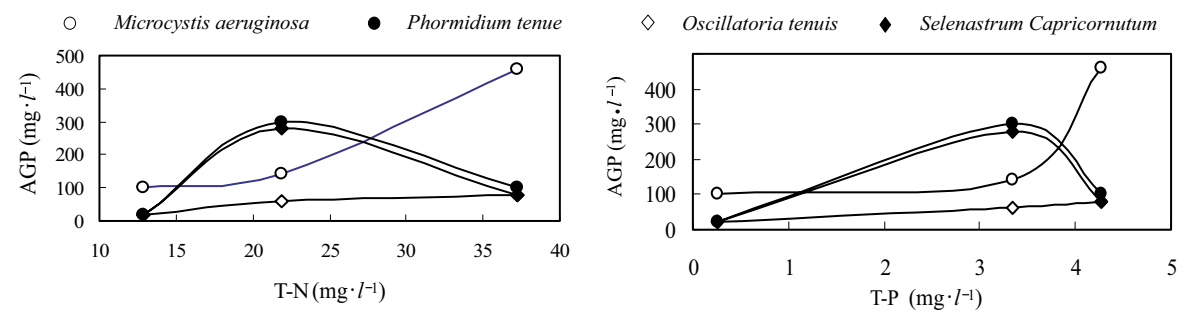

Fig. 6 Relationship between AGP values and T-N, T-P concentrations 
or has positively correlated with DON of wastewater (Abdelhamid et al., 1992; Berman et al., 1999, Yoshida et al., 1996, Stepanauskas et al., 1999). And we also noted the AGP of Oscillatoria tenuis have statistically sig-nificant correlation with organic phosphorus $(\mathrm{P}<0.01)$. Although it is not so significant, AGP of Selenastrum capricornutu and Phormidium tenue are also shown to have closed relationship with phosphorus source. For Oscillatoria tenuis, organic phosphorus is more obvious and for Selenastrum capricornutu, Phormidium tenue, inorganic phosphorus is more obvious. The results suggest that the components of the nitrogen and phosphorus not only decide the direct or indirect $\mathrm{N}$ and $\mathrm{P}$ usage by phytoplankton, but also decide that different algal species can exploit these sources with varying capabilities so that different $\mathrm{N}$ and $\mathrm{P}$ substrates may selectively stimulate the development of dominant algal species.

$\mathrm{SF}$ wetland removed $\mathrm{P}$ from wastewater efficiently and relieves the wastewater from algal growth to some extent. Calculating according to phosphorus concentration and AGP results, total AGP of Selenastrum capricornutu and Microcystis aeruginosa at phosphorus concentration of $1 \mathrm{mg} / \mathrm{l}$ are $381.6 \mathrm{mg} / \mathrm{l}$ and $76.3 \mathrm{mg} / \mathrm{l}$. For Selenastrum capricornutu, other researchers also get the AGP of $500 \mathrm{mg} / l$ (Gerhold et al., 1975) and $430 \mathrm{mg} / \mathrm{l}$ (Shiroyama et al., 1975) at phosphorus concentration of $1 \mathrm{mg} / l$. They are very closed the results of this study. It suggests that evaluation of Selenastrum capricornutu is standard to great extent. But for Microcystis aeruginosa, other researchers got the result of 1250 or $950 \mathrm{mg} / \mathrm{l}$ at phosphorus concentration of $1 \mathrm{mg} / \mathrm{l}$ (Gerloff and Skoog, 1957), they are more than 10 times of the results in this study. It suggests that the growth of Microcystis aeruginos is closed correlated with nutrient status, which is also reflected in Table 6. After treated by wetlands with different structure, even though nutrients concentration is closed each other, the status is different. This result also bring out the fact that evaluation of Microcystis aeruginos is very dependent on water quality such as the status of nutrients inside, and further study is necessary for the standardization of Microcystis aeruginos evaluation.

Apart from nutrient status, the N/P ratio is also recognized to decide $\mathrm{P}$ limiting or $\mathrm{N}$ limiting for algal growth. The N/P ratio of 20 has been used to classify $\mathrm{N}$ or $\mathrm{P}$ limiting in Japan lakes by Ministry of Environment. Same phenomena have been also reported in papers. It was reported that under the N/P ratio above 20:1, algal bloom will experience only if excess phosphorus becomes available and if $\mathrm{N}: \mathrm{P}$ ratios are below 20:1, nitrogen is the limiting nutrient and the estuary will experience algal blooms if excess nitrogen becomes available (Jaworski, 1981).

As shown in Figure 7, investigating the change of N/P ratio of the effluents, the N/P ratio of SF wetland system is more than 50 and $\mathrm{P}$ is limiting factor for algal growth, and the N/P ratio of FWS effluent is only 6.3 and

Table 6 Correlation analysis between nutrients status and AGP

\begin{tabular}{|c|c|c|c|c|c|c|c|c|}
\hline & \multicolumn{2}{|c|}{ Selenastrum capricornutum } & \multicolumn{2}{|c|}{ Microcystis aeruginosa } & \multicolumn{2}{|c|}{ Phormidium tenue } & \multicolumn{2}{|c|}{ Oscillatoria mougeotti } \\
\hline & $\begin{array}{l}\text { Pearson's } \\
\text { correlation }\end{array}$ & $\begin{array}{l}\text { Pearson's } \\
\text { significance }\end{array}$ & $\begin{array}{l}\text { Pearson's } \\
\text { correlation }\end{array}$ & $\begin{array}{l}\text { Pearson's } \\
\text { significance }\end{array}$ & $\begin{array}{l}\text { Pearson's } \\
\text { correlation }\end{array}$ & $\begin{array}{l}\text { Pearson's } \\
\text { significance }\end{array}$ & $\begin{array}{l}\text { Pearson's } \\
\text { correlation }\end{array}$ & $\begin{array}{l}\text { Pearson's } \\
\text { significance }\end{array}$ \\
\hline $\mathrm{T}-\mathrm{N}$ & 0.0709 & 0.8939 & 0.9636 & 0.0020 & 0.1294 & 0.8070 & 0.9423 & 0.0049 \\
\hline Organic-N & 0.0012 & 0.9983 & 0.9799 & 0.0006 & 0.0600 & 0.9102 & 0.9167 & 0.0101 \\
\hline Inorganic-N & 0.1065 & 0.8409 & 0.9534 & 0.0032 & 0.1648 & 0.7551 & 0.9537 & 0.0032 \\
\hline $\mathrm{T}-\mathrm{P}$ & 0.5000 & 0.3125 & 0.7495 & 0.0863 & 0.5501 & 0.2581 & 0.9938 & 0.0001 \\
\hline Organic-P & 0.3696 & 0.4709 & 0.8373 & 0.0375 & 0.4236 & 0.4026 & 0.9994 & 0.0000 \\
\hline Inorganic-P & 0.5683 & 0.2393 & 0.6936 & 0.1265 & 0.6157 & 0.1931 & 0.9816 & 0.0005 \\
\hline
\end{tabular}

\begin{tabular}{|c|c|c|c|c|}
\hline $\begin{array}{l}\text { Most significant } \\
\text { Factor }\end{array}$ & Inorganic $\mathrm{P}^{* * *}$ & Organic $\mathrm{N}^{*}$ & Inorganic $\mathrm{P}^{* *}$ & Organic $\mathrm{P}^{*}$ \\
\hline
\end{tabular}




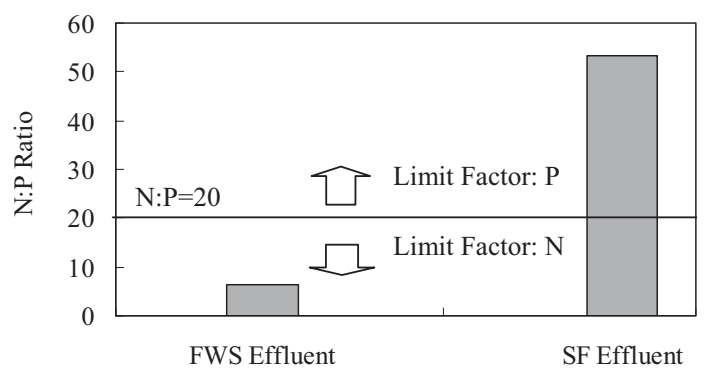

Fig. 7 Change of $\mathrm{N}$ : $\mathrm{P}$ ratios after treated by constructed wetlands

$\mathrm{N}$ is limiting factor of algal growth. Nearly $67 \%$ of the lakes in U.S and $80 \%$ of the lakes in Italy are phosphorus limiting,(Gakstatter et al., 1976; Chaudani and Vighi, 1974), discharging of treated water like SF effluent will help to relieve the tendency of eutrophication in lakes.

\section{CONCLUSIONS}

Considering effluent water quality and its potential of resulting algae bloom, SF wetland is more preferable to use because of high pollutants removal rate, stable operation and lower risk for resulting algae bloom after effluent is discharged into lakes and rivers. SF wetlands reduce the phosphorous source obviously and make the effluent phosphorus limiting for algal growth. On the contrary, the FWS wetland changed the $\mathrm{N} / \mathrm{P}$ ratio and made it preferable for algal growth. Nutrient status will decide its availability for algal growth and influence AGP. For Phormidium tenue, Selenastrum capricornutum and Oscillatoria tenuis, AGP is more influenced by phosphorus and AGP of Microcystis aeruginosa is more influenced by nitrogen. Apart from traditional parameters, the status of nitrogen and phosphorus should also be considered.

\section{REFERENCES}

1 ) Abdelhamid, MI, Shaabandessouki, SA, and Skulberg, OM: Water Quality of the rive Nile in Egypt, 2. Water Fertility and toxicity evaluated by an algal growth potential test. Arch. Hydrobiol., 3, 311337 (1992)
2 ) APHA: Bioassay methods for aquatic organisms. In: Standard methods for examination of Water and Wastewater, $15^{\text {th }}$ edition. American Public Health Association, Washington, DC, USA (1980)

3 ) Berman, T. and Chava, S.: Algal growth on organic compounds as nitrogen sources, J. Plankton Res., 21(8), 14231437 (1999)

4 ) Chaudani, G. and Vighi, M.: The N/P ratio and tests with Selenastrum to predict eutrophication in lakes. Wat. Rse., 8, 1063 -1069 (1974)

5 ) Couillard, D. and Li, J.F.: Assessment of Manure-Application effects upon the runoff water quality by algal assays and chemical analyses, Environ. Pollut. 80, 273-279 (1993)

6 ) Danuta, L. and Andrew, D.: Tertiary wastewater treatment through constructed wetland ecosystems. Env. Protection Eng., 18 (1-2), 13-23 (1992)

7 ) Gakstatter, J.H., Allum, M.O., and Omernik, J.M.: Lake eutrophication: results from the national eutrophication survey, In: EPA(Ed.), Water Quality Criteria Research of the U.S EPA Proceedings of an EPA-sponsored symposium, EPA-600/3-76-079 (1976)

8 ) Gale, P.M., Reddy, K.R., and Graetz, D.A.: Nitrogen removal from reclaimed water applied to constructed and natural wetland microcosms. Wat. Env. Res., 65 (2), 162-168 (1993)

9 ) Gerhold, R. M.: Algal nutritional bioassays of lake Wylie, North Carolina, In: E. Joe Middlebrooks, Donna H. Falkenborg and Thomas E. Maloney (Eds.), Biostimulation and Nutrient Assessment, p175-220, Utah State University and EPA (1975)

10) Gerloff, G. C. and Skoog. F.: Nitrogen as limiting factor for the growth of Microcystis aeruginosa in southern Wisconsin lakes. Ecology, 38, 556-560 (1957)

11) Harberl, R.: Constructed wetlands: a chance to solve wastewater problems in developing countries. Wat. Sci. Tech., 40 (3), 11-17 (1999)

12) Iwata, Y., Sugahara, I., Kimura, T. et al.: Growth Potential of Gymnodinium 
mikimotoi in Gakasho Bay, Nippon Suisan Gakk., 63 (4), 578-584 (1997)

13) Marvan, P., Pribil, S, and Lhotsky, O.: Algal Assays and Monitoring Eutrophication, Schweizerbarts che verlag, Stuttgart, 253pp (1979)

14) Miller, W.E., Greene, L.C., and Shiroyama, T.: The selenastrum capricornutum PRINTZ algal assay bottle test. $126 \mathrm{pp}$, EPA-600/9-78-812, U.S. Environment Protection Agency, Oregon (1978)

15) Nicholas, D.S.: Removal of nutrients from treated municipal wastewater by wetland vegetation. J. WPCF, 55, 485491 (1983)

16) Peter F.B.: A mass balance method for assessing the potential of artificial wetlands for wastewater treatment. Wat. Res., 24 (6), 689-697 (1990)

17) Procella, D.B., Grau, P., Huang, C. H., Radimsky, J., Toerien D.F., and Pearson E.A.: Provisional Algal Assay Procedures, 180pp. First annual report of the sanitary Engineering Research Laboratory, Berkley (1970)

18) Reed, C. S. and Ronald, W. C.: Natural systems for waste management and treatment, McGraw-Hill, Inc. (1993)

19) Reed, S.C. and Brown, D.S.: Constructed wetland design-the first generation. Wat. Env. Res., 64 (6), 776-781 (1992)
20) Shiroyama, T., W.E. Miller, and J.C Greene: Effect of nitrogen and phosphorus on the growth of Selenastrum capricornutum. In: EPA(Ed.)

21) Stepanauskas, R., Leonardson, L., and Tranvik L.J.: Bioavailability of wetlandDerived DON to freshwater and marine bacterioplankton, Limnol. Oceanogr., 44 (6), 1477-1485 (1999)

22) Sudo. R.: Microbiology for purification of environment, KODANSHA Scientific, Tokyo Japan (1983)

23) Yoshida Y. and Okono T.: Relationship between the occurrence of microcystis bloom and DON:DIN ratios in Lake Suwa, Nippon Suisan Gakk., 62 (4), 631637 (1996)

24) Yoshida Y., Nakahara H., and Kuwae. A.: Mechanisms on the occurrence of Mirocystis bloom at harbors in the north basin of lake Biwa, Nippon Suisan Gakk., 62 (2), 230-235 (1996)

25) Japan Sewage works Association.: Biota in Water Supply System in Japan, Tokyo Japan (1992)

26) Jacoby JM., Collier DC et al.: Environmental factors associated with a toxic bloom of Mirocystis aeruginosa, Canadian Journal of Fisheries and Aquatic Sciences, 57 (1), 231-240 (2000)

(Submitted 2005. 4. 14)

(Accepted 2005. 8. 15) 